\title{
Spirituality for democracy and social cohesion versus the spirituality of money
}

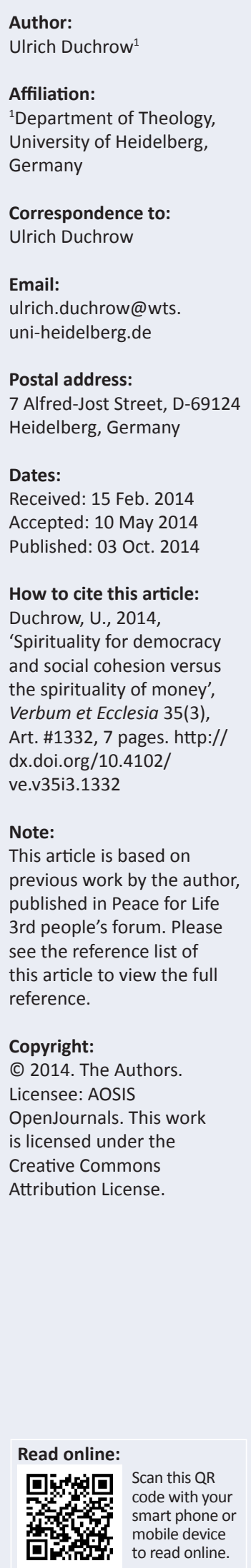

We live in a life-killing global system, and thus, we are called by our own biblical basis re-read in the spirit of other than Western traditions - to search for life-giving alternatives and to develop democracy accordingly. However, this is not a geographical exercise. We cannot count on South Africa as a place where Ubuntu is practiced or on South Korea living in communities according to Sangsaeng. The reason is that Western civilisation, with its own spirituality, has permeated all corners of the earth. My thesis is that this is the spirituality of money; biblically speaking, of Mammon. Before we can talk about a spirituality for democracy and social cohesion, we need to address the spirituality of the status quo in order to understand what the alternative could be. The issue gets complicated by the new insight that Western civilisation has deep roots in history; in fact a history of almost 3000 years. Only by looking at this history can we really understand how money did not only change socio-economic and political structures but also hearts, minds and the spirituality of people.

Intradisciplinary and/or interdisciplinary implications: This article challenges the normal Western assumption that democracy is but a political issue of voting every 4 or 5 years. Instead it shows that real democracy is linked to economic and social justice, as well as to deep cultural and spiritual roots. Authors should carefully identify the contextual perspective they challenge, identifying the potential results of the proposed research and whether it calls for a change in traditional discourse as well as whether such a change is possible. Key insights into the research results and its future function should be revealed.

Today we are faced with life-killing civilization, manifested in economic injustice, ecological destruction, the threat of Empire, and the escalation of religious conflicts. This compels us to urgently explore the possibility of life-giving civilization which affirms relationships, co-existence, harmony with creation, and solidarity with those who struggle for justice. This quest finds meaning in Ubuntu and Sangsaeng. (Transforming Theology 2007)

\section{Introduction}

Today we are experiencing psychological and spiritual suffering and disease amongst a growing number of people. In India, about 54 farmers on average commit suicide daily out of despair because they have been driven into debt beyond their means (Martin \& Kakde 2006). Workers suffer increasing stress and anxiety whilst middle-class people fall into depression, which in 2020 will presumably be the second largest illness according the World Health Organization (WHO). In contrast, nearly all people are making their decisions according to the one yardstick: 'What is in it for me?' They are thus motivated by an egocentric spirituality. What are the roots of all of this?

\section{The spirituality of money in the Axial Age and in the capitalist civilisation of modernity}

My thesis is that what we are now experiencing started nearly 3000 years ago within what is called the Axial Age, beginning in the 8th century BCE in the whole of Eurasia, from Greece to China. At that time, a new economy started to appear in daily life, built on money and private property. It had tremendous social as well as psychological and spiritual effects. To analyse what happened then helps to understand what is happening today. Looking at the responses to this development from the different faiths and philosophies in Israel or Judah, India, China and Greece may also help us to better understand the tasks and possibilities of a spirituality of democracy and social cohesion in our age.

It was the philosopher Karl Jaspers who coined the term Axial Age (Jaspers 2010). According to him, the experience of violent crises between 800 and 200 BCE might have prompted the parallel efforts of the prophets, the Buddha, Confucius, Daoism and Greek philosophy to find new foundations for living together. He characterised the new approach as intellectual and 
spiritual (geistig), looking only marginally at the economic and political context. Recently Karen Armstrong and, based on her findings, Jeremy Rifkin took up this theory, looking particularly at war and violence as causes for the responses within the different cultures (Armstrong 2006; Rifkin 2009). José María Vigil (2012) also recently published a chapter in his book Theology of axiality and axial theology. As far as the socio-historic context of the Axial Age is concerned, my thesis comes closest to what Graeber (2011) worked out in his book Debt: The first 5,000 years, although he is not that interested in the religious responses. Combining his insights with my own research (cf. Duchrow \& Hinkelammert 2004), let me summarise how the new economy affects the ancient societies and spiritualities.

Money as unit of account was used in the palaces and temples of Mesopotamia as early as around 3000 BCE, but the ordinary economy of people in daily life functioned via a system of mutual credit. This changed when soldiers and mercenaries became professionals and war-making was raised to previously unknown levels. They had to be paid. The most important wage was the spoils. As precious metal could easily be transported, it started circulating in little pieces as a kind of money. Around $600 \mathrm{BCE}$, authorities in Lydia, India and China started nearly simultaneously to coin the metal in order to pay mercenaries and soldiers. With these practical currencies, local markets also developed for daily transactions by the normal people. This means that cash and unified markets are the children of war.

At the same time slaves, usually prisoners of war, but by now increasingly also debt slaves, were turned into a negotiable commodity. This is why Graeber calls this new system the military-coinage-slavery-complex. A kind of vicious circle emerged. New professional armies looted precious metals from temple or palace treasuries, jewellery of women and slaves from the populace. The slaves had to work in the mines to produce more metal for the coinage. The coins were paid to the soldiers and stimulated the local markets and so on. The whole system only functioned as long as it expanded through further conquest. So it is no surprise that this system was easily wedded to imperialism. Increasingly, the empires also requested the payment of tribute in the form of money. This development found its first climax in the Hellenistic-Roman empires.

On this basis, the logic and spirituality of calculated exchange in markets emerged. Goods for daily needs were exchanged with money as the unit of account. Money became the 'one' in the variety of commodities, but not as a 'thing', detached from the social process in which people recognise its value, as the Buddhist economist, Karl-Heinz Brodbeck, points out (Brodbeck [2009] 2012). This means that the daily use of money also changed the soul and the thinking of people. Besides communicating by speech, namely using words (logos), they communicated by calculating in money (ratio). In so doing, the individual ego gained precedence over relations in community.
The developments above were furthered by the fact that, in the process of exchange in the market, the money owner had more power than the producer of goods. Money as such offered access to the market whilst the product first had to be in demand. Coping with this risk is only possible by having as much money as possible. One of the 'sages of antiquity', Pittakos of Mytilene, underlined this by saying: 'Profit is insatiable' (Binswanger 1995:34). He does not say: 'The one who makes profit is insatiably greedy'. What he says is that an economy in which money is made a commodity is inherently greedy. This is why, in our new book, Franz Hinkelammert and I speak of 'greedy money' (Duchrow \& Hinkelammert 2012). There is an 'objective' base for greed to accumulate money without limits.

The other implication of the new money economy is that money gives the right to private property beyond personal use. Money gives access to the market, cushions the risks, measures the exchange value and gives access to property rights. Combined with the development of hierarchies and classes in larger societies, money and private property started to determine the economic, social and political power of people within societies.

In any case, the new economy led to greed and the desire to accumulate limitless money. The institutionalisation of this greed was inscribed in interest. Debtors had to pay back more than they had borrowed, for example to purchase seed. They also had to put up their own land as security. If they could not pay back their debt plus interest, they lost their land and their family had to work as debt slaves for the creditor. Thus private property and money came into existence at the same time and led to debt slavery and loss of land. At the same time, creditors could collect more and more land, money and debt slaves. This is what scholars have called the emergence of a class society in antiquity (Kippenberg 1977).

Private property and money also reinforced the male domination of patriarchy since only men could own property, which was a way of giving them political power, too. The house father (in Greek: despotes, in Latin: dominus) was seen as the owner of the land, women, children, slaves and cattle. This meant that democracy in Ancient Greece was also a democracy of male property owners. In Roman law, private property even received the status of an absolute. Men were legally allowed to use, misuse or destroy it. Both the Hellenistic and Roman empires built on a calculating, conquering spirituality, from the household to the emperor.

So the result of introducing money as commodity and private property as an absolute, combined with imperial conquest, was an increased division in societies between masters and slaves, men and women, a more and more precarious situation of small farmers and, in general, a dire impoverishment and suffering for the majority of people. This was not just a structural problem, because money also changed people's souls. Besides communicating through speech and cooperation, they started calculating, 
which included calculating each other's performance in competition. So the problem was not just structural, but it took on a psychological and spiritual dimension.

Before looking at the religions and philosophies resisting these developments in the Axial Age, let us briefly analyse how the modern capitalist civilisation built on the early money and private-property economy, giving it a new dynamic. In early capitalism, from the 13th to the 14th century CE, the market set out to conquer one sphere of life after the other. The basic step was the privatisation of land as commons through enclosures, subjecting agriculture to the mercantile coordination of labour. Another new element was the introduction of compound interest. However, the most decisive new element was the invention of double-entry book keeping in the upper Italian trade and banking cities. Here everything was calculated according to debit and credit, costs and return, input and output with one goal only: to gain maximum profit. Double-entry bookkeeping was not just a social technique but the decisive characteristic of a new worldview. People started looking at the world as a functional mechanism to produce profit for oneself. The calculation of utility followed the means-end rationality, which is the typical way of thinking in European modernity that meanwhile dominates the whole world. As the economy serves the one purpose of maximising profits, normal people judge everything according to a single yardstick: 'What's in it for me?'

It was Thomas Hobbes and John Locke in the 17th century CE who worked out the Western concepts of the human being and democracy (Duchrow \& Hinkelammert 2004). Hobbes defined the human being as a competitive atomised individual striving for limitless accumulation of wealth, power and reputation, this in the context of the political body, called Leviathan, whose blood is defined as money. Locke defined the human being as property owner and democracy as the political order which has the only purpose of protecting property.

So, structural, cultural and personal greed came to be seen as something positive. Finally, Jeremy Bentham and Adam Smith defined greed and egoism as a virtue and the decisive motor of the economy. The mechanism of continuously re-investing the profit in new projects in order to gain higher profits created an obsessive accumulation machine. Money that is constantly re-invested for accumulation purposes is called capital. Capital is not simply money but money or assets in monetary terms invested for getting more money. It can also be frozen to capital in the form of machines serving accumulation. So, greedy money is the exact description of the nature of capital, of profit thirsty for more profit. This is why capitalism is the precise term for the economic system and the form of society of Western modernity. Market economy is a euphemism in order to avoid touching the taboo. If you want to use this term in a capitalist context, you need to say 'capitalist market economy', because in the past there were, and in the future there will be, other kinds of market economies. There can, for example, be exchange markets without money, but there can also be markets with money although these may not have money in the form of a commodity geared at accumulation.

Industrial capitalism deepened the division of labour and increased the split between the classes. However, its key new feature is the increased throughput of energy and resources for profit's sake, aggravated by the fact that consumerism has to be stimulated for the sake of maximum capital accumulation. The result of this shift is only visible now as we face the energy and ecological crises. Karl Marx (Marx \& Engels 2012) was prophetic when he stated:

Capitalist production, therefore, develops technology, and the combining together of various processes into a social whole, only by sapping the original sources of all wealth - the soil and the laborer. (s.p.)

He also analysed the obsession with accumulation by the commodity-money mechanisms as fetishism, driving people and societies even against reason. This means that capitalism is more than an economic system. It is a religion - an insight further developed by Walter Benjamin in his essay on capitalism as religion. This is exactly what we experience today as growth fetishism is destroying the earth. It can only prevail because people have internalised the spirituality of a calculating money subject.

Today this fetishism has taken the form of financial capitalism after it turned out that infinite growth is not possible in a finite world. Within the financial sector, the growth obsession has turned to speculation, with ballooning financial assets in all kinds of forms. However, it is not without a link to the real economy because when the balloons burst, as we experienced in the years following 2007, the neoliberal governments take real money from the working tax payers and throw it into the voracious jaws of the money owners and their agents, the banks. This shows that our formal democracy is unable to serve the interest of the people. It is a democracy of the banks, by the banks, for the banks. As this policy increases the debt of the public budgets, big capital is blackmailing the governments to pay even higher interest rates and curb social benefits. It seems certain that the whole system will one day collapse, thereby increasing the suffering of people even more. Financial capitalism is the ultimate climax of a development starting in the Axial Age.

Its spiritual dimension may be demonstrated by a poem about gold composed by the Swiss poet Mascha Madörin from advertisements of banks - especially because gold is one of the most fateful natural gifts to South Africa and its history:

Gold is validation; its promise carries weight.

Gold is surprise; it exceeds the greatest expectations.

Gold is security; on its stability the world depends.

Gold has charisma; it never loses its shine.

Gold is faithfulness; it never betrays its owner.

Gold is eternity; its fascination outlives time. 
Gold is secret; no one can completely fathom its allure.

Gold is gratitude; it knows how to express itself in immortal words.

Gold is love; there can hardly be a more noble manifestation.

Gold is trust; its value endures.

Gold is affection; it can express feelings better than a thousand words.

Gold is longing; its attraction never fades. (Madörin 1989) ${ }^{1}$

For me, the conclusion is that we are not dealing with this or that crisis but that this whole civilisation is death-bound, not just the economy. It is only because the majority of the people and, to some extent, all of us are imprisoned in the same kind of logic, spirit and practice that the system is still able to operate. Are there possibilities of structural and personal transformation to find a new culture of life which could be nurtured? Before addressing our own options, let us look at some responses by the Axial Age religions. Of course, we have to realise from the beginning that all religious communities today have to a large extent assimilated to the dominating civilisation. So we have to realise with the classic South African Kairos Document that we are in the midst of a struggle between state or capital theology, church theology and prophetic (or liberation) theology when we look at the traditions.

\section{Counter-cultural spiritualities in the Axial Age religions}

In this section, I briefly discuss the responses of the Axial Age religions and philosophies to the then emerging imperial money and private-property economy and its effects on people's spirituality (Duchrow \& Hinkelammert 2012):

- The prophets and the Torah in Israel or Judah responded with the call for justice and legal provisions.

- The Buddha responded with overcoming the three poisons of greed, aggressive hatred and the illusion of the ego by mindful insight in the mutual interdependency of all beings, the new ways of living together in the Sanghas and admonition to the rulers.

- Laozi responded with giving priority to the gentle over the hard in the way of the Dao and Confucius with the constant rectification of fulfilling one's role in an ordered society. Socrates responded with putting the search for the arete of the soul over wealth and reputation, Plato with justice in the politeia and Aristotle with his critique of the chremastic accumulation of money and the ethics and politics of the natural economy of the house and exchange without accumulation.

- Jesus called for the decision between God's justice and the money idol Mammon, highlighting the religious character of money.

- Muhammad condemned the illusion of limitless wealth accumulation, prohibited charging interest on loans (on the basis of the biblical heritage) and asked for the sharing of wealth through taxes (Zakat) in order to get people out of poverty.

1.Put together (in German) by Mascha Madörin from Omega advertisement texts (Madörin 1989:49).

2.All of this is elaborated in Duchrow and Hinkelammert (2012).
Let me summarise the response of the Jesus movement and the early church on the basis of the Hebrew Bible. Historically it seems that the prophet Amos in the second part of the 8th century BCE was the first to react to the upcoming money and private-property economy and its spirituality. His central theme was the threat to the small farmers. They were losing their possessions through seizures, being sold into slavery for excessive debts whilst the women were abused as debt slaves etc. (cf. Am 2:6-8). Against the destruction of human and social relations through the mechanisms of money and private property, Amos places justice in the centre, correcting all power asymmetries (Am 5:24):

Let justice roll down like waters,

and righteousness like an ever-flowing stream.

Other prophets of Israel and Judah followed the same line: Hosea, Micah, Isaiah, Jeremiah. The latter identifies the knowledge of God with doing justice to the poor (Jr 22:16). The prophets and their followers were a minority in Israel and Judah. It was only King Josiah who made a difference in the second part of the 7th century BCE. It was under his rule that the message of the prophets started to be implemented in the form of legal reforms that eventually led to the Torah. Central to this process is the book of Deuteronomy. Here you find the Decalogue, presenting God as the liberator from slavery and therefore demanding and protecting just human relations because this is the only way in which freedom can be secured (Dt 5:6-21). It is not by accident that the last of the Ten Commandments is about greed and accumulation:

Neither shall you covet your neighbor's wife.

Neither shall you desire your neighbor's house,

or field; or male or female slave, or ox, or donkey,

or anything that belongs to your neighbor.

The socio-economic laws are found in Deuteronomy 14-15, later elaborated in Leviticus 25 . They contain the prohibition of interest, regular release of debts and slaves, et cetera. When the political economy and spirituality of greed and conquest became totalitarian in the Hellenistic empires, the Jewish faithful (chassidim) reacted with apocalyptic underground literature characterised by resistance and hope for God's intervention. The classical text for this is the book of Daniel. In chapter three, we find the narrative of three Jewish men defying the emperor's demand that everybody should fall down and worship the golden statue. Chapter seven tells about a vision of Daniel: the empires in the shape of greedy predatory beasts are overcome by God's new order coming down from heaven in the shape of a human being. The message is that the human, the image of God, will have the victory over the beast-like, destructive imperial order. That is the hope feeding persistent resistance.

This is the tradition on which Jesus, his movement and the early church are building new messianic communities in the spirit of God within the context of the Roman Empire. This I understand as a second wave of the Axial Age faiths and philosophies. (I regard Islam as the third wave, building on the biblical traditions, in the context of the Arab merchant 
society). Jesus proclaims that God's new domination-free order with a human face, announced by Daniel, is beginning in his presence. It is the suffering, the poor and the outcast who become the first subjects of this new order which turns the imperial hierarchy upside down. The first will be last and the last will be first. He creates a spirituality of trust in God's care overcoming the external and internal rule of Mammon, the idol of collecting treasures in the form of the accumulation of money and property. 'Strive first for the kingdom of God and God's justice, and all these things will be given to you as well' (Mt 6:33).

It is important to realise that Jesus does not only liberate the poor to change their own lives and spirituality and build communities of solidarity, but he also acts politically in relation to the existing institutions. One of his key actions in this regard is the confrontation with the Jewish collaborators with the Romans, the priestly elites in the temple, the central bank of that time (Mk 11:15-19). The key text of God's and Jesus' identification with the people impoverished by and suffering from economic injustice is found in Matthew 25:31ff. Here the victims, the hungry, the thirsty et cetera are portrayed as the yardstick for all people and peoples to be accepted in the final judgement. The judge is the Human One of Daniel 7. This text is crucial for interfaith relations and interfaith solidarity for justice and a new spirituality because those judged are not judged by the criteria of belonging to this or that religion, but by providing for the basic needs of the least ones with whom Jesus identifies.

The early Christian communities followed Jesus on this path. The classical text is Acts 4:32-35. The community voluntarily shares property, especially those who have landed property and houses. This balancing of the relations within the community is portrayed as the fulfilment of the Deuteronomy Torah by quoting: 'There was not a needy person among them' (cf. Dt 15:4).

A key witness for our issue is the Apostle Paul. He adds two important insights to the Jesus tradition. The first is that reason can be co-opted by greed. In his first letter to the Corinthians, he shows that reason is folly when it orientates itself to wisdom in the service of the strong, the rich and the mighty. (Today we know this very well when, for example, scientists work in the service of Transnational Corporations [TNCs] to smokescreen the ecological dangers of a product which destroys ecosystems). So wisdom is only true wisdom when it orients itself to the criteria of the weak, vulnerable or despised, in order to be truly inclusive. Secondly, Paul shows in the letter to the Romans that the law, meant to serve life in community, can also be co-opted by greed (Rm 6, 7). In that case, it kills. (Today we can see this in the case of debt mechanisms: when the law that debt has to be repaid is made an absolute, it can kill by producing hunger and even death through Structural Adjustment Programs). Therefore, the overarching criterion for law must be love and solidarity. In Roman 8, Paul elaborates that the only way to do justice is by living in this new spirit of the Messiah in new messianic communities. They will revolutionise the Roman Empire with this new spirituality. This is the whole purpose of Paul's counter-cultural mission.

I thus summarise the core of the Hebrew Bible and the messianic Second Testament in relation to human beings suffering from the reality and spirituality of economic injustice: it is the identification of the God of Israel and Jesus with the impoverished people. Therefore, justice in the hearts and minds of people and justice in community relations and institutions are the key contribution of the biblical traditions towards interfaith solidarity for overcoming the structural and spiritual sins of the prevailing civilisation.

What does all this mean in the context of our searching for a spirituality for democracy and social cohesion today?

\section{Searching a spirituality for democracy and social cohesion today}

Let us first draw some conclusions from the historical review. The first is that democracy and social cohesion is in principle not possible in a capitalist civilisation. Here the power of money rules, systemically corrupting the economic and political institutions as well as the spirituality of the people. The second is that you cannot change the situation by merely changing institutions. Even if they could be changed, the calculating ego-spirituality of the money-subjects would corrupt them again. Similarly, you cannot change the money spirituality of the people without changing the structures because the structures would continue to corrupt the hearts and minds of the people. The third complicating factor is a psychological one (cf. Duchrow \& Hinkelammert 2012). How can you explain that the majority of the world's population is suffering from social and psychological destruction by the dominating system, but only a minority is standing up to resist and work for alternatives? Here very complex psychological factors play a role: leading the losers to fatality and the middle-class to illusions in their consciousness. What could be a way out?

The starting point must be that the capitalist civilisation is death-bound. If it were to continue, humanity and earth will stumble from one catastrophe to the next until the earth could not bear human life any more. The reason is very simple. Capital is defined by the dynamics that it must grow without limits. This is the single most important factor creating the necessity of economic growth. Under industrial conditions, this cannot happen without material throughput which needs natural resources and produces waste. How can anything grow without limits in a finite world? This means that our 3000-year-old civilisation must be transformed into a post-capitalist new culture or die.

However, this argument by itself will neither create a conversion (metanoia) of people's hearts and minds, nor will it create the political will to change institutions. It just creates 
fear and stimulates the drive for short-range immediate survival and gain. What is needed is the long-range horizon of any search for a new spirituality as well as for a new political economy, namely a post-capitalist culture. In order to complement this ambiguous long-range perspective by a more motivating one, it is necessary to create opportunities for people to experience that post-capitalist behaviour, mentality and socio-economic structures offer a better quality of life. This means that the local-regional level is a privileged area from which a new spirituality, economy and politics must emerge - in spite of the fact that, simultaneously and finally, the global system must be changed. The present system is constructed top-down. The alternative can only be developed bottom-up.

Now let us look into some of the details of developing a spirituality for democracy and social cohesion today. If it is true that the pillars of the dominating system are money and private property linked with egocentric individualism, imperial and patriarchal violence, it is at these points that theology has its crucial tasks today.

The key for a new money order is that money must be turned from a commodity for accumulation into a public good servicing the real economy and managed democratically. It has to be an instrument for exchange and credit, not a goal. This is already practiced on local and regional levels with regional, interest-free parallel currencies. In the long run, it has to be envisaged at the global level too. Keynes already proposed this in 1944 at the Bretton Woods conference when he suggested a global central bank with the reserve currency 'bancor'. The USA at that point rejected this proposal because they wanted the dollar to be world money. As the present financial system will move from one crisis to the next, a moment may come when Keynes' proposal will have a chance. The banks in a new order will have only the role of managers of public money, not as the winners through interest, speculation, et cetera without labour. This is already happening on a small scale with cooperative and democratic banks. In Austria, a democratic bank is just in the stage of being implemented, called 'Bank for the Common Good' (cf. http://www.demokratische-bank.at/).

A new property order will be built on the commons, the world as a gift to be used for life not as privatised commodity. This starts with land, water, air and seed but includes common cultural goods produced by collectives such as the internet. Consequently all basic goods and services for the satisfaction of basic needs of people must be public, including transport, education and health. It does not mean that all this should be turned into state property. Public property must and can be organised as near to the affected people as possible. There are many legal forms by which this can be done (Duchrow \& Hinkelammert 2004). Together with the struggle against the empire and serving capital, the struggle against privatisation is the main alliance partner besides initiatives building up such new order from below.
Without developing economic democracy, there will be no real political democracy. The only way to overcome the present situation is to rebuild the political institutions from below on the material basis of economic democracy. In this way, state institutions are being subjected to the criteria of the social, economic, ecological and cultural human rights from the start and not only in a secondary manner. All of these criteria have one reference point: the right to life. The subjects, therefore, have to be real human beings, not just the property owners. Whoever wants to implement human rights must join the struggle to overcome capitalism. Postcapitalist political institutions have to be built up, and this is possible. Representative democracy will, in this way, be complemented by economic, direct and participatory democracy. This presupposes that all movements engaged in the struggles have to have a political dimension. They have to reappropriate the very term 'democracy', which capitalism has hijacked. Realising that capitalism and democracy are irreconcilable, the movements have to liberate democracy from its perversion. ${ }^{3}$

In this context, theology has a crucial role in transforming the egocentric money spirituality of people by demonstrating how mutual relationships in cooperation, empathy and solidarity are the basis for a good human life (buen vivir). Here all original sources of the Axial Age religions radiate an abundant spiritual power. However, these will not be grasped by people just by informing them. The insight of liberation theologies, that practice is the starting and end point of doing theology, turns out to be crucial in this regard.

How do we go from the old to the new order of becoming human in solidarity and creating a humane society ${ }^{4}$ The key bridge is the solidarity protest movements, resistance and the work for alternatives. They are the emerging subject (change agent) that rejects and transforms the totalitarian functional mechanisms of cost-benefit calculation, which are the law that kills. They represent the various aspects of the social and psychological destruction that cause suffering to people, societies and our planet. They form the countervailing power that aims at responding to the holistic personal and social needs that are neglected by the disembedded capitalist economy. They care for society and Mother Earth as a whole. Joining them is the way to healing the fatality and illusion. In this way, people become acting subjects, reappropriating the stolen resources for the common good, liberating themselves from the psychological and mental distortions caused by the system. This means that people cannot be healed from their egocentric spirituality individually. The goal is the way. Without walking and working together in concrete terms, they cannot experience the better quality of life in postcapitalist behaviour and structures.

Empirically this is initially possible at points where people are touched directly in their basic material conditions of

3.The political theory for this approach has been developed by Enrique Dussel's (2008) politics of liberation.

4.For the following, cf. chapter 12 in Duchrow and Hinkelammert (2012). 
life. From here, they can expand their engagement into the transformation of systemic economic and political institutions. Worldwide there are a host of local-regional post-capitalist socioeconomic alternatives. One key concept in this regard is (social) solidarity economy (Arruda 2008). In Brazil, solidarity economy has even achieved public support. The Lula government established a State Secretariat for Solidarity Economy, supporting the civil-society networks. The year 2006 saw a joint conference on the subject, bringing government and movements together.

There are four areas in particular in which alternative localregional alternatives can flourish (cf. Douthwaite 1996):

- post-capitalist ways to deal with exchange and money

- cooperative banking

- alternative energy

- local production, marketing and consumption.

On the larger level of society, there are strategic points of departure for concrete popular struggles. These include:

- work for all - against unemployment

- gender justice - against sexism

- life-giving agriculture - against agribusiness

- the supply of public goods and services - against privatisation

- solidarity social insurance - against capital-based pension funds

- tax justice - against bottom-up redistribution

- eco-justice - against destroying the earth.

These kinds of struggles are the breeding ground for developing a spirituality for democracy and social cohesion. For South Africa, the subversive memory of the United Democratic Front (UDF) against apartheid could be of help. It was in this context that new theological and spiritual discoveries like the South African Kairos Document of 1985 or the development of Muslim liberation theology were made (cf. Esack 1997). What would happen if all existing efforts for local-regional post-capitalist alternatives and all the ongoing and popular struggles would form a new United Front for Post-capitalist Democracy and Social Cohesion (UFD)? Would this praxis not be a testing ground for all faith communities in the country to rediscover the anti-Mammon spirituality of their original sources of the Axial Age as a counter-cultural resource in the common struggle against death-bound capitalism and for a new base-democratic culture of life?

\section{Conclusion}

Recent research has shown that the introduction of money into daily life economies during the Axial Age has had dramatic consequences not only for the economy but also for social and political life as well as for the whole of civilisation. It became the roots of modernity and has reached a climax in financial capitalism. As this civilisation turns out to be unsustainable, even to threaten life on earth, a whole new culture of life has to be developed. As this must be based on a new spirituality transcending the calculating mentality of the money civilisation, the role of religion becomes crucial. Whilst the majority of religions have assimilated the money civilisation, liberation theologies within all religions go back to the responses of the original, reacting critically against the social, political and spiritual consequences of the new economy. This includes a new theory of religion and also shows practical ways of participatory democracy, democratising the economy, regaining social cohesion and developing a life-giving culture. New interdisciplinary research in religious, economic and political studies can build on these findings. Particularly, a new field of contextual studies is opened on religions and the political economy.

\section{Acknowledgements Competing interests}

The author declares that he has no financial or personal relationship(s) that may have inappropriately influenced him in writing this article.

\section{References}

Armstrong, K., 2006, The great transformation: The beginning of our religious traditions, Anchor Books/Random House, New York.

Arruda, M. (ed.), 2008, Exchanging visions of a responsible, plural, solidarity economy, ALOE and PACS, Rio de Janeiro.

Binswanger, H.C., 1995, 'Die Marktwirtschaft in der Antike: Zu den ökonomischen Lehren der griechischen Philosophen', in K. Füssel \& F. Segbers (eds.), So lernen die Völker des Erdkreises Gerechtigkeit: Ein Arbeitsbuch zu Bibel und Ökonomie Ein Arbeitsbuch zu Bibel und Ökonomie, pp. 23-35, Exodus, Luzern.

Brodbeck, K.-H., [2009] 2012, Die Herrschaft des Geldes. Geschichte und Systematik, Wissenschaftliche Buchgesellschaft, Darmstadt.

Douthwaite, R., 1996, Short circuit: Strengthening local economies for security in an unstable world, The Lilliput Press, Dublin.

Duchrow, U. \& Hinkelammert, F.J., 2004, Property for people, not for profit: Alternatives to the global tyranny of capital, Zed Books in association with the Catholic Institute for International Relations and the World Council of Churches, London and Geneva.

Duchrow, U. \& Hinkelammert, F.J., 2012, Transcending greedy money: Interreligious solidarity for just relations, Palgrave MacMillan, New York. http://dx.doi. org/10.1057/9781137290021

Duchrow, U., 2013, 'Faith-based Response to the Crisis of Imperial Capitalism', in Peace for Life 3rd people's forum, S63-S75, viewed n.d., from http://www.oikotree.org/ wp-content/uploads/3rd-people-forum-programme.pdf

Dussel, E., 2008, Twenty theses on politics, Duke University Press, Durham and London. http://dx.doi.org/10.1215/9780822389446

Esack, F., 1997, Qur'an liberation \& pluralism: An Islamic perspective of interreligious solidarity against oppression, Oneworld, Oxford.

Graeber, D., 2011, Debt: The first 5,000 years, Melville House, New York.

Jaspers, K., 2010, The origin and goal of history, Routledge Revivals, London.

Kippenberg, H.G., 1977, 'Die Typik der antiken Entwicklung', in H.G. Kippenberg (ed.) Seminar: Die Entstehung der antiken Klassengesellschaft, pp. 9-61, Suhrkamp, Frankfurt 1977, Concer.

Madörin, M., 1989, Weltwoche, 07 December, p. 49.

Martin, M. \& Kakde, S., 2006, From debt trap to death trap: Victims of 'free market' An enquiry into farmers' suicide, Vikas Adhyayan Kendra, Mumbai.

Marx, K. \& Engels, F., 2012, Capital, vol. 1, viewed 03 August 2012, from http://www. marxists.org/archive/marx/works/subject/quotes

Rifkin, J., 2009, The empathic civilization: The race to global consciousness in a world in crisis, Penguin Books, London.

Transforming Theology, 2007, WCC-CWM ChangSeong Consultation on Transforming Theology and Life-giving civilization held on 12-17 August 2007, viewed 03 August 2012, from http://www.oikoumene.org/de/dokumentation/documents/oerkgeneralsekretaer/speeches/13-08-07-chang-seong-korea-transforming-theology. html

Vigil, J.M., 2012, 'Theology of axiality and axial theology', Voices 3/4, 167-178. 